Vol II. No. 1, September 2017, hlm. 69 - 74

Available online at www.jurnal.una.ac.id/indeks/jmp

\title{
ANALISIS KESULITAN SISWA PADA MATERI TEOREMA SISA DI SMA NEGERI 1 AEK KUASAN
}

\author{
Ira Permata Nasution', Irwan ${ }^{2}$ \\ Pendidikan Matematika Universitas Asahan, \\ Email: irapn@gmail.com
}

\begin{abstract}
This study aims to determine the difficulties of the students in solving the remaining theorem problem. To know the students' difficulties in solving the problem of residual terema, researchers use the table of student difficulty as a guide to find the factors causing student difficulties in solving the problem of the remaining theorem. Samples taken are students of class XI IPA SMA Negeri 1 Aek Kuasan academic Year 2015/2016 amounted to 34 students. The difficulties of students in grade XI IPA SMA Negeri 1 Aek Kuasan Academic year 2015/2016 in solving the problems of the remaining theorem are: (1) Students difficulty in determining the appropriate formula with the problem because students do not understand the concept of the problem, (2) The Difficulties students seen in the lack of accuracy of students in solving the problem, (3) The Students have mistake in the counting process because less accurate the caunting process.
\end{abstract}

Keywords: Student Difficulties Analysis, Material Time Theorem

\begin{abstract}
Abstrak
Penelitian ini bertujuan untuk mengetahui kesulitan yang dihadapi siswa dalam menyelesaikan soal teorema sisa. Untuk mengetahui kesulitan - kesulitan siswa dalam menyelesaikan soal - soal Terema sisa, peneliti menggunakan tabel kesulitan siswa sebagai pedoman mencari faktor penyebab kesulitan siswa dalam menyelesaikan soalsoal teorema sisa. Sampel yang diambil yaitu siswa kelas XI IPA SMA Negeri 1 Aek Kuasan Tahun Pelajaran 2015/2016 berjumlah 34 siswa. Kesulitan yang dilakukan siswa kelas XI IPA SMA Negeri 1 Aek Kuasan Tahun Pelajaran 2015/2016 dalam menyelesaikan soal-soal Teorema sisa adalah : (1) Siswa kesulitan dalam menentukan rumus yang sesuai dengan soal dikarenakan siswa tidak memahami konsep soal, (2) Kesulitan siswa terlihat pada kurangnya ketelitian siswa dalam menyelesaikan soal, (3)Siswa salah dalam proses perhitungan karena kurang teliti dalam proses perhitungan.
\end{abstract}

Kata Kunci : Analisis Kesulitan Siswa, Materi Teorema Sisa 
Vol II. No. 1, September 2017, hlm. 69 - 74

Available online at www.jurnal.una.ac.id/indeks/jmp

Penting dalam kehidupan. Pendidikan merupakan kebutuhan yang harus dipenuhi untuk mendapatkan kualitas Sumber Daya Manusia (SDM) yang baik. Menurut Trianto (2009:1) "Pendidikan yang mampu mendukung pembangunan dimasa mendatang adalah pendidikan yang mampu mengembangkan potensi siswa, sehingga yang bersangkutan mampu menghadapi dan memecahkan problema kehidupan yang dihadapinya".

Matematika adalah ilmu yang memiliki sifat khas yaitu: objek bersifat abstrak, menggunakan lambang-lambang yang tidak banyak digunakan dalam kehidupan seharihari, dan proses berpikir yang dibatasi oleh aturan-aturan yang ketat. Permendiknas nomor 22 tahun 2006 menyatakan tujuan siswa mempelajari matematika adalah sebagai berikut: (1) memahami konsep matematika, menjelaskan keterkaitan antar konsep dan mengaplikasikan konsep atau logaritma, secara luwes, akurat, efisiensi, dan tepat dalam pemecahan masalah; (2) menggunakan penalaran pada pola dan sifat, melakukan manipulasi matematika dalam membuat generalisasi, menyusun bukti, atau menjelaskan gagasan dan pernyataan matematika; memecahkan masalah yang meliputi kemampuan memahami masalah, merancang model matematika, menyelesaikan model dan menafsirkan solusi yang diperoleh; mengomunikasikan gagasan dengan simbol, table, diagram, atau media lain untuk memperjelas keadaan atau masalah; (5) menghargai sikap kegunaan matematika dalam kehidupan, yaitu memiliki rasa ingin tahu, perhatian, dan minat dalam mempelajari matematika, serta sikap ulet dan percaya diri dalam pemecahan masalah. Hal ini untuk mencapai tujuan siswa dalam mempelajari matematika.

Pada kenyataannya, matematika merupakan bidang studi yang paling sulit oleh siswa. Seperti yang dikemukakan oleh Abdurrahman (2012:202) "Dari berbagai bidang studi yang diajarkan di sekolah. Matematika merupakan bidang studi yang paling sulit oleh para siswa, baik yang tidak berkesulitan belajar dan lebih-lebih bagi siswa yang berkesulitan belajar". Masih banyak siswa yang mengalami kesulitan dalam mempelajari matematika, dan matematika dianggap sesuatu hal yang menakutkan dan sebisa mungkin untuk dihindari. Ketika mendengar matematika serta merta yang muncul dipikiran identik dengan kata "sulit". Akibat dari kesulitan yang dialami siswa dalam belajar terutama dalam pembelajaran matematika, hal ini akan berpengaruh pada hasil belajar matematika dan keberhasilan belajar matematika itu sendiri.

Kesulitan yang dialami siswa dapat terlihat dari sulitnya siswa dalam menyelesaikan permasalahan matematika, terutama pada materi teorema sisa. Kesulitan siswa dalam menyelesaikan permasalahan pada materi teorema sisa dapat terlihat dari banyaknya kesalahan siswa dalam menyelesaikan permasalahan atau soalsoal.

Kesulitan belajar adalah suatu kondisi proses belajar yang ditandai hambatan-hambatan tertentu untuk mencapai hasil belajar. Beberapa gejala sebagai pertanda adanya kesulitan belajar, misalnya: (1) Menunjukkan prestasi yang rendah atau di bawah 
Vol II. No. 1, September 2017, hlm. 69 - 74

Available online at www.jurnal.una.ac.id/indeks/jmp

rata-rata yang dicapai oleh kelompok kelas; (2) Hasil yang dicapai tidak seimbang dengan usaha yang dilakukan; (3) Lambat dalam melakukan tugas-tugas belajar; (4) Menunjukkan sikap yang kurang wajar; (5) Menunjukkan tingkah laku yang berlainan. Dari gejala-gejala diatas guru bias menginterpretasikan bahwa siswa kemungkinan mengalami kesulitan belajar (Ahmadi \& Supriyono, 2004:93)".

Secara garis besar faktor-faktor penyebab timbulnya kesulitan belajar terdiri atas dua macam, yaitu: faktor intern meliputi ranah cipta, rasa dan karsa) ekstern yang meliputi lingkungan keluarga, lingkungan masyarakat an lingkungan sekolah

\section{METODE}

Dalam hal ini peneliti melakukan pendekatan non-eksperimen dan penelitian ini merupakan penelitian kualitatif. Penelitian kualitatif merupakan penelitian yang bertujuan mencari kebenaran suatu penelitian untuk dijadikan sebagai sampel kemudian menjadi acuan dalam suatu penelitian. Penelitian ini digunakan untuk mengetahui kesulitan-kesulitan yang dialami siswa dalam menyelesaikan permasalahan atau soalsoal Teorema sisa di kelas XI IPA SMA Negeri 1 Aek Kuasan Tahun Pelajaran 2015/2016.

Berdasarkan metode penelitian kualitatif, kehadiran peneliti dilapangan sangat penting mengingat peneliti merupakan instrument kunci utama dalam mengungkapkan makna sekaligus sebagai alat pengumpul data, maka peneliti harus terlibat langsung dengan orang-orang yang diteliti.
Dalam penelitian ini, peneliti terjun langsung ke lapangan sebagai pengamat penuh untuk mengumpulkan dan mengamati data yang dibutuhkan. Peneliti berencana melaksanakan penelitian ini di kelas XI IPA SMA Negeri 1 Aek Kuasan pada semester genap Tahun Pelajaran 2015/2016. Adapun data-data yang dibutuhkan peneliti adalah data-data mengenai kesulitan siswa dalam menyelesaikan soal-soal Teorema sisa di kelas XI IPA SMA Negeri 1 Aek Kuasan pada semester genap Tahun Pelajaran 2015/2016.

Penelitian ini akan dilaksanakan di SMA Negeri 1 Aek Kuasan di Jalan Aek Loba Pekan Kecamatan Aek Kuasan Tahun Pelajaran 2015/2016.

Sumber data dalam penelitian ini adalah subjek dari mana data diperoleh. Subjek dari penelitian ini yaitu siswa kelas XI IPA SMA Negeri 1 Aek Kuasan Tahun Pelajaran 2015/2016 yang terdiri dari 1 kelas, yang berjumlah 34 orang siswa.

Untuk mengumpulkan data yang diperlukan, dalam penelitian ini penulis menggunakan tes dan wawancara. Tes yang digunakan berbentuk tes essay yang terdiri dari lima butir soal yang mewakili dari materi pokok teorema sisa. Sumber pembuatan soal penulis mengambil soal dari buku pegangan siswa dan guru. Sebelum tes digunakan sebagai alat pengumpul data, perangkat tes tersebut terlebih dahulu dilakukan validasi.

Wawancara adalah proses memperoleh keuntungan untuk tujuan penelitian dengan cara tanya jawab, sambil bertatap muka antara pewawancara dengan responden. 


\section{Gurnal}

\section{MATEMATICS PAEDAGOGIC}

Vol II. No. 1, September 2017, hlm. 69 - 74

Available online at www.jurnal.una.ac.id/indeks/jmp

Wawancara yang dimaksud dalam penelitian ini adalah wawancara yang dilakukan terhadap subjek penelitian. Wawancara yang dilakukan bertujuan untuk mencari sebanyak-banyaknya hal yang berkaitan dengan kesalahan dan kesulitan yang mereka hadapi dalam menyelesaikan permasalahan yang ada, baik permasalahan yang diujikan maupun materi yang berkaitan dengan permasalahan tersebut, serta untuk mengetahui apa faktor-faktor penyebab kesulitan tersebut. Wawancara yang dilakukan bersifat terbuka dan berpedoman pada lembar jawaban mereka sebagai hasil tes.

\section{HASIL DAN PEMBAHASAN}

Pada penelitian ini subjek yang disunakan adalah 34 orang siswa. Setelah ujian terhadap subjek oleh

Peneliti pada materi teorema sisa selesai dilaksanakan maka penulis membuat gambaran hasil ujian siswa berdasarkan diagram batang berikut ini:

Diagram hasil ujian siswa

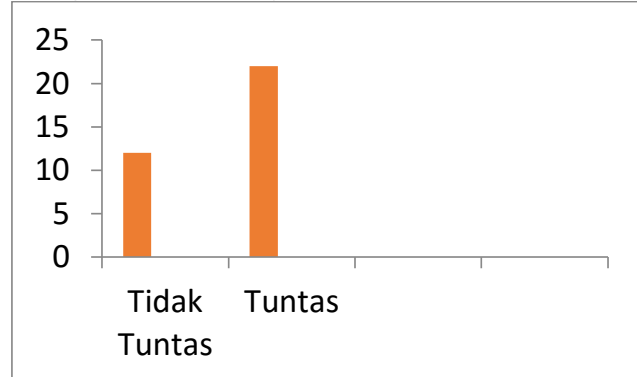

Berdasarkan paparan data hasil ujian yang telah dilakukan terhadap subjek, maka peneliti memaparkan temuan penelitian. Kesalahan yang dibuat siswa maka dibuat analisis terhadap jawaban-jawaban hasil ujian yang telah dilakukan dan diperkuat dengan hasil wawancara terhadap siswa yang melakukan kesalahan.

1. Terhadap Hilman Arief Wijaya

Jawaban salah nomor 1

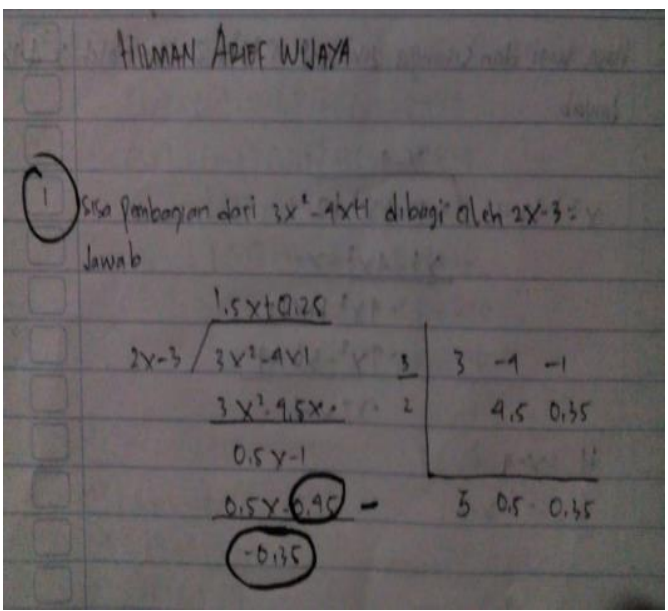

\section{Hasil wawancara:}

Guru : Apa yang menyebabkan anda kesulitan sehingga menyebabkan kesalahan dalam menyelesaikan soal nomor 1 ?

Siswa : Saya salah dalam perkalian, dan saya kurang teliti melihat tandanya sehingga saya salah dalam menyelesaikannya.

2. Terhadap Cyndy Nardianti Jawaban salah nomor 2

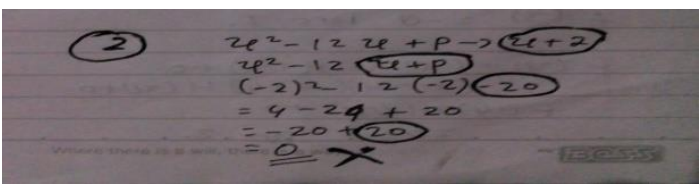

Hasil wawancara:

Guru : Apa yang menyebabkan anda kesulitan menyelesaikan soal nomor 2 sehingga jawaban anda salah?

Siswa : Saya kurang mengerti cara menyelesaikannya, jadi saya selesaikankan dengan cara saya sendiri.

Kesimpulan penulis berdasarkan jawaban dari Cyndy Nardianti bahwa 
Vol II. No. 1, September 2017, hlm. 69 - 74

Available online at www.jurnal.una.ac.id/indeks/jmp

siswa kurang memahami soal dan cara menyelesaikannya, sehingga sulit dalam menentukan rumus dan membuat siswa menyelesaikannya dengan cara yang mereka ketahui sendiri. Akibat dari kesalahan dalam penggunaan rumus, maka hasil kerja siswa salah

Kesimpulan penulis berdasarkan jawaban Hilman Arief Wijaya yaitu melakukan kesalahan dalam aspek operasi perhitungan, dan kurang telitinya dalam menyelesaikan soal sehingga menyebabkan kesalahan pada hasil akhir.

kita mengetahui apa bentuk kesulitan siswa dalam menyelesaikan soal-soal teorema sisa, yaitu sebagai berikut :

1) Siswa kesulitan dalam menentukan rumus yang sesuai dengan soal dikarenakan siswa tidak memahami konsep soal. 2) Kesulitan siswa terlihat pada kurangnya ketelitian siswa dalam menyelesaikan soal. 3) Siswa salah dalam proses perhitungan karena kurang teliti dalam proses perhitungan.

Selain itu, peneliti juga melakukan pengecekan keabsahan temuan, guna untuk membuat hasil penelitian menjadi lebih absah. Agar data bisa memperoleh keabsahan, maka peneliti menggunakan teknik :

\section{a. Perpanjangan keabsahan peneliti dilapangan}

Sebelum melakukan penelitian secara formal, peneliti terlebih dahulu menyerahkan surat permohonan penelitian kepada pihak sekolah yang akan diteliti. Hal ini dimaksudkan agar dalam melakukan penelitian, peneliti mendapat tanggapan yang baik mulai dari awal sampai akhir penelitian.

b. Pembahasan sejawat

Teknik ini dilakukan dengan cara mengekspos hasil sementara atau hasil akhir yang diperoleh dalam bentuk diskusi dengan rekan-rekan sejawat.

\section{SIMPULAN}

Dari pembahasan hasil penelitian, kesulitan yang dilakukan siswa kelas XI IPA SMA Negeri 1 Aek Kuasan Tahun Pelajaran 2015/2016 dalam menyelesaikan soal-soal Teorema Sisa adalah :

1. Siswa kesulitan dalam menentukan rumus yang sesuai dengan soal dikarenakan siswa tidak memahami konsep soal.

2. Kesulitan siswa terlihat pada kurangnya ketelitian siswa dalam menyelesaikan soal.

3. Siswa salah dalam proses perhitungan karena kurang teliti dalam proses perhitungan.

\section{saran}

Berdasarkan hasil kesimpulan:

1. Setiap guru/pendidik sebaiknya memerhatikan pencapaian hasil siswa dan dapat meningkatkan hasil kerja siswa.

2. Sebagai guru/pendidik harus menguasai materi pelajaran agar dapat memberikan materi yang lebih luas dalam proses pembelajaran guna menambah pengetahuan siswa agar terwujudnya prestasi siswa.

3. Bagi siswa kelas XI IPA SMA Negeri 1 Aek Kuasan Tahun Pelajaran 2015/2016 dalam proses belajar hendaknya lebih 


\section{MATEMATICS PAEDAGOGIC}

Vol II. No. 1, September 2017, hlm. 69 - 74

Available online at www.jurnal.una.ac.id/indeks/jmp

meningkatkan minat belajar serta pemahaman tentang masalah matematika khususnya materi Teorema siswa sehingga dapat menyelesaikan soal-soal dan dapat aktif dalam proses pembelajaran.

\section{DAFTAR RUJUKAN}

Suprijanto, H. Sigit. 2009. Matematika 2 SMA Kelas XI Program IPA. Jakarta: Yudhistira

Trianto. 2009. Mendesain Model Pembelajaran Inovatif Progresif. Surabaya: Kencana Prenada Media Group.
Purwanto. 2008. Evaluasi Hasil Belajar. Surakarta: Pustaka Pelajar

Ahmadi, Abu \& Widodo Supriyono. 2004. Psikologi Belajar. Jakarta: Rineka Cipta

Umar, Tirtarahardja \& S. L. La Sulo. 2005. Pengantar Pendidikan. Jakarta: Rineka Cipta. 


\section{Gurval}

\section{MATEMATICS PAEDAGOGIC}

Vol II. No. 1, September 2017, hlm. 69 - 74

Available online at www.jurnal.una.ac.id/indeks/jmp 